\title{
Prevalence and geographical distribution of bovine eurytrematosis in cattle slaughtered in northern Paraná, Brazil ${ }^{1}$
}

\author{
Jefferson R. de Azevedo 2,3, Renate C. Mannigel' ${ }^{2}$, Adriana Z. Agulhon², Thiago R. \\ Borba $^{2,3}$, Adriana W. Barbiéri², Daniella C. L. de Oliveira², Selwyn A. Headley ${ }^{4}$ \\ and Vanderly Janeiro 5
}

\begin{abstract}
Azevedo J.R., Mannigel R.C., AgulhonA.Z., BorbaT.R., Barbieri A.W., Oliveira D.C.L., Headley S.A. \& Janeiro V. 2004. Prevalence and geographical distribution of bovine eurytrematosis in cattle slaughtered in northern Paraná, Brazil. Pesquisa Veterinária Brasileira, 24(1):23-26. Laboratório de Patologia Veterinária, Centro Universitário de Maringá, Av. Guedner 1610, Jd. Aclimação, Maringá, PR 87050-390, Brazil. E-mail: headleysa@ cesumar.br A retrospective study of cattle slaughtered in northern Paraná during 2000 was performed to determine the prevalence and geographical distribution of bovine eurytrematosis (BE), as identified by the Federal Inspection Service (SIF). The cattle was from different regions of the State of Paraná; all regions had cattle parasitized by Eurytrema spp. BE was identified in $12.1 \%$ $(12,534 / 103,411)$ of the total number of cattle inspected. Prevalence of animals parasitized by Eurytrema spp varied from 8.3\%(Region G, São João do Caiuá, 1,069/12,914) to 40.5\%(Region R, Ponta Grossa, 225/555). BE was more prevalent during the month of March (1.6) and markedly reduced during May (-2). A possible seasonal predominance of BE was identified: comparatively fewer cases occurred from April to August, while there was a peak from December to March. The study indicates that bovine eurytrematosis is hypoendemic and occurs in almost all geographical regions of the State of Paraná. The prevalence within this State is variable and may be directly related to factors of the biological cycle of the trematode, particularities of each region, and environmental conditions.
\end{abstract}

INDEX TERMS: Cattle, eurytrematosis, epidemiology, parasitology.

\begin{abstract}
RESUM 0.- [Prevalência e distribuição geográfica de euritrematose bovina em animais abatidos no norte do Estado do Paraná.] Um estudo retrospectivo de bovinos abatidos no norte do Paraná durante o ano de 2000 foi realizado para determinar a prevalência e a distribuição geográfica da euritrematose bovina (EB), identificada pelo Serviço de Inspeção Federal (SIF). Bovinos foram originários de todas as localizações geográficas do Estado do Paraná; todas as regiões apresentaram gado parasitado por Eurytrema spp. EB foi identificado em 12,1\%(12.534/10.3411) de todos os animais
\end{abstract}

\footnotetext{
${ }^{1}$ Received on December 16, 2002.

Accepted for publication on October 31, 2003.

${ }^{2}$ Acadêmico, Curso de Medicina Veterinária, CESUMAR.

${ }^{3}$ Bolsista, Programa de Iniciação Científica do CESUMAR (PICC/CESUMAR).

${ }^{4}$ Laboratório de Patologia Veterinária, Centro Universitário de Maringá (CESUM AR), Av. Guedner 1610, Jardim Aclimação, Maringá, PR 87050-390. E-mail: headleysa@ cesumar.br

${ }^{5}$ Depto Estatística, Universidade Estadual de Maringá, PR.
}

abatidos. A prevalência dos animais parasitados por Eurytrema spp variou entre 8,3\% (Região G, São João do Caiuá; 1.069/ 12.914 ) e 40,5\%(Região R, Ponta Grossa; 225/555). EB foi mais prevalente durante 0 mês de março $(1,6)$ e marcadamente reduzida em maio $(-2,0)$. Uma possível predominância sazonal foi identificada: comparativamente poucos casos ocorreram durante os meses de abril a agosto, enquanto um pico foi observado entre dezembro a março. Este estudo indicou que a euritrematose bovina ocorre em quase todas das regiões geográficas e está hipoendêmica no Estado do Paraná. A prevalência no Estado é variável e pode está diretamente relacionada aos fatores do ciclo biológico do trematódeo, a particularidade de cada região e dos fatores ambientais.

TERMOS DE INDEXAÇÃO: Bovinos, euritrematose, epidemiologia, parasitologia.

\section{INTRODUCTION}

Eurytrematosis is caused by trematodes (Eurytrema coelomaticum and Eurytrema pancreaticum) that live mainly in the pancreatic ducts but occasionally in the bile ducts of rumi- 
nants and other animals (Travassos et al. 1969, Soulsby 1982, Jubb 1993). In Brazil, bovine eurytrematosis (BE) has been more related to $E$. coelomaticum than to other species (Travassos et al. 1969, Mattos Jr \& Vianna 1987). The parasite requires two intermediate hosts to complete its life cycle; the first intermediate host is a land snail (Bradybaena similaris), and the second are various species of grasshoppers, Conocephalus maculatus, Conocephalus chimensis, Conocephalus melas, and Conocephalus gladiator, of the Tettigoniidae family (Travassos et al. 1969, Mattos Jr \& Vianna 1987).

Infection by Eurytrema spp in cattle induces a chronic interstitial pancreatitis with subsequent ductal obstruction (Jubb 1993, Mannigel et al. 2002), which often leads to condemnation of the organ by the Federal Inspection Service (SIF) during routine inspection (Mattos Jr \& Vianna 1987, Headley 2000). Over the last years the prevalence of $B E$ identified in Brazilian abattoirs has increased dramatically, but there is insufficient documentation of these changes, and epidemiological information relative to infection trends in Brazil is fundamental for effective control measures.

Recently published epidemiological data on the prevalence of this trematode in Brazil are lacking, while those existing are outdated. A former epidemiological study made in Minas Gerais reported a frequency of $17.15 \%$ (Brant \& Costa 1963), while there was found $80 \%$ infestation in the State of São Paulo (Mattos Jr \& Vianna 1987). The present study determined the prevalence and geographic distribution of BE identified in cattle slaughtered in the region of Maringá, northern Paraná, during 2000, as reported by SIF.

\section{MATERIALS AND METHODS}

Data were obtained from the official archives of the Federal Inspection Service (SIF), Maringá, State of Paraná, Brazil, by a retrospective study. The total number of cattle submitted for

Table 1. Geographical distribution of the origin of cattle slaughtered in northern Paraná, Brazil, 2000

\begin{tabular}{|c|c|c|}
\hline Regions & Municipalities within each region & Reference municipality \\
\hline A & Diamante do Oeste;Guaíra;Terra Roxa & Diamante do Oeste \\
\hline B & Foz do Iguaçu; Matelândia; Medianeira; Santa Terezinha de Itaipu & Foz do Iguaçu \\
\hline $\mathrm{C}$ & Loanda Marilena; Porto Rico; Santa Cruz do Monte Castelo; São Pedro do Paraná & Loanda \\
\hline $\mathrm{D}$ & $\begin{array}{l}\text { Antônia; Cafezal do Sul; Cruzeiro do Oeste; Douradina; Esperança Nova; Icaraima; Iporã; Ivaté; Maria Helena; Mariluz; } \\
\text { Nova Olímpia; Perobal; Pérola; Querência do Norte; Santa Isabel do Ivaí; Santa Mônica; São Jorge do Patrocínio; Tapira; } \\
\text { Umuarama; Vila Alta; Xambrê }\end{array}$ & Tapira \\
\hline $\mathrm{E}$ & Alto Piquiri; Brasilândia do Sul; Cascavel; Corbélia; Francisco Alves; Goioerê; Moreira Sales; Quarto Centenário; Ubiratã & Cascavel \\
\hline $\mathrm{F}$ & Catanduvas; Céu Azul; Lindoeste; Ramilândia; Realeza; Três Barras do Paraná; Vera Cruz do Oeste & Vera Cruz do Oeste \\
\hline G & $\begin{array}{l}\text { Cruzeiro do Sul; Diamante do Norte; Guairaça; Inajá; Jardim Olinda; Nova Londrina; Paranacity; Paranapoema; Santa } \\
\text { Maria; Santo Antonio do Caiuá; São João do Caiuá; Terra Rica }\end{array}$ & São João do Caiuá \\
\hline $\mathrm{H}$ & $\begin{array}{l}\text { Alto Paraná; Amaporã; Arapuã; Araruna; Atalaia; Cianorte; Cidade Gaúcha; Doutor Camargo;Emgenheiro Beltrão; } \\
\text { Guaporema; Indianópolis; Ivatuba; Jussara; Mandaguaçu; Mirador; Nova Aliança do Ivaí; Nova Esperança; Ourizona; } \\
\text { Paiçandu; Paraíso do Norte; Paranavaí; Peabiru; Planaltina do Paraná; Presidente Castelo Branco; Quinta do Sol; Rondon; } \\
\text { São Carlos do Ivaí; São Jorge do Ivaí; São Manuel do Paraná; São Tomé; Tamboara; Tapejara; Tuneiras do Oeste; Uniflor }\end{array}$ & Paranavaí \\
\hline I & $\begin{array}{l}\text { Altamira do Paraná; Boa Esperança; Campina da Lagoa; Campo Mourão; Corumbataí do Sul; Iretama; Janiopolis; Laran- } \\
\text { jal; Luisiana; Mamborê; Mato Rico; Nova Cantú; Palmital; Roncador }\end{array}$ & Roncador \\
\hline J & $\begin{array}{l}\text { Bela Vista; Campo Bonito; Candói; Cantagalo; Guaraniaçu; Laranjeiras do Sul; Marquinho; Nova Laranjeiras; Reserva do } \\
\text { Iguaçu }\end{array}$ & Nova Laranjeiras \\
\hline K & São Pedro & São Pedro \\
\hline $\mathrm{L}$ & $\begin{array}{l}\text { Cafeara; Centenário do Sul; Colorado; Guaraci; Itaguajé; Lobato; Nossa Senhora das Graças; Porecatu; Santa Inês; Santo } \\
\text { Inácio }\end{array}$ & Centenário do Sul \\
\hline M & $\begin{array}{l}\text { Iguaraçu; Ângulo; Apucarana; Arapongas; Astorga; Bom Sucesso; Cambira; Faxinal; Fênix; Flórida; Itambé; Jaguapitã; } \\
\text { Jandaia do Sul; Kaloré; Mandaguari; Marialva; Maringá; Marumbi; Munhoz de Melo; Novo Itacolomi;; Pitangueiras; Prado } \\
\text { Ferreira; Rio Bom; Rolândia; Sabáudia; Santa Fé; São João do Ivaí; Sarandi; Cambé; Londrina; Marilândia do Sul; Tamarana }\end{array}$ & Santa Fé \\
\hline $\mathrm{N}$ & $\begin{array}{l}\text { Barbosa Ferraz; Boa Ventura de São Roque; Candido de Abreu; Godoy Moreira; Grandes Rios; Ivaiporã; Jardim Alegre; } \\
\text { Manuel Ribas; Nova Tebas; Pitanga; Santa Maria do Oeste; Rio Branco do Ivaí; Rosário do Ivaí }\end{array}$ & Grandes Rios \\
\hline 0 & Guairacá; Guarapuava & Guairacá \\
\hline $\mathrm{P}$ & Conselheiro Mairinck; Cornélio Procópio; Ibaiti; Jataizinho; Nova Fátima; Rancho Alegre; Ribeirão do Pinhal; Sertaneja & Cornélio Procópio \\
\hline Q & Castro; Ortigueira; Reserva; Tibagi & Ortigueira \\
\hline $\mathrm{R}$ & Ipiranga; Palmeira; Ponta Grossa; Rio Claro do Sul & Ponta Grossa \\
\hline S & Carlópolis; Joaquim Távora; Tomazina & Carlópolis \\
\hline $\mathrm{T}$ & Arapoti & Arapoti \\
\hline $\mathrm{U}$ & Porto Amazonas & Porto Amazonas \\
\hline V & Rancharia (SP); Rosário Oeste (MT); Japorá (MS); Cruzmaltina (PR) & Cruzmaltina \\
\hline
\end{tabular}

aMuncipalities that submitted the largest number of animals for slaughter were considered as reference municipality for each region. 
slaughter and inspected daily from January to December 2000 was recorded as 103,441 . This represented $1 \%(103,441 / 9,900,885)$ of the Paraná cattle population and $12.9 \%(103,441 / 800,831)$ of cattle slaughtered during the year 2000 (SIDRA 2003). Cattle positive for BE were defined as those of which the pancreas demonstrated parasitic forms of Eurytrema spp. Daily records were transformed into monthly totals and prevalences were established.

All animals submitted for slaughter originated from 200 municipalities within the State of Paraná and were grouped into 2,752 subunits by SIF. These animals were subdivided into 20 geographical regions (Regions A-V) based on their municipality of origin. Due to the diverse geographical locations of cattle sent for slaughter, the 200 muncipalities were grouped into 20 principal geographical locations to facilitate the analysis of collected information. Municipalities with the largest number of animals sent for slaughter within each region were considered as reference towns for geographical localizations (Table 1). Cattle originating from neighbouring States and from municipalities within the State of Paraná that submitted less than $0.5 \%(517 / 103,411)$ of the total number were grouped separately.

Monthly prevalence was determined by comparing the number of animals parasitized by Eurytrema spp with the total number of animals submitted for slaughter. The relative monthly prevalence of animals infested was the number of animals parasitized relative to the total number parasitized during the year 2000 (Smith 1995). The prevalence of cattle in each geographical region was determined by comparing the number of animals infested with the total number of animals received from each region (Table 2). The comparative prevalence (Westgard \& Hunt 1973) of animals parasitized was the monthly prevalence compared with the relative prevalence of animals infested (Table 3). Using the statistical test, comparing two binomial proportions - large sample (Westgard \& Hunt 1973, Agresti 1990, Johnson 1992), differences within the monthly and relative prevalences were determined, and the comparative prevalence evaluated.

\section{RESULTS}

The cattle slaughtered originated from different geographic regions of the State of Paraná (Table 1). Almost all geographical locations within this State were represented. A small percentage of animals slaughtered originated from neighbouring States; these were united with seven regions (Regions $A, B, K$, $\mathrm{P}, \mathrm{S}, \mathrm{T}$, and $\mathrm{U}$ ) that presented less than $0.5 \%$ of the total number of animals submitted for slaughter, and were collectively considered as Region V (Table 1).

During the year 2000, an average of $12.1 \%(12,534 / 103,411)$ of the total number of cattle inspected by the Federal Inspection Service (SIF), Maringá, PR, had parasitic forms of Eurytrema spp (Table 2). This represented 1.6\%(12,534/800,831) of all cattle slaughtered, and only $0.13 \%(12,534 / 9,900,885)$ of the estimated effective cattle population within the State of Paraná during the year 2000 (SIDRA 2003).

The prevalence of animals parasitized (Table 2) by Eurytrema spp in the regions studied varied from 8.3\%(Region G, São João do Caiuá, 1,069/12,914) to 40.5\%(Region R, Ponta Grossa, 225/555). The relative prevalence of cattle parasitized by Eurytrema spp varied from $4.3 \%$ in August to $12.5 \%$ in November (Table 3). These differences were significantly different $(P<0.05)$ within each other. The relative prevalences demonstrated during the months of January, June, August and
Table 2. Geographical prevalence of cattle infested with Eurytrema spp in Paraná, Brazil, 2000

\begin{tabular}{cllccc}
\hline & \multicolumn{1}{c}{ Origin } & & \multicolumn{3}{c}{ Animals slaughtered } \\
\cline { 1 - 2 } \cline { 5 - 6 } Regions & $\begin{array}{c}\text { Reference } \\
\text { muncipalities }\end{array}$ & & Total & $\begin{array}{c}\text { Infested by } \\
\text { Eurytrema spp }\end{array}$ & $\begin{array}{c}\text { Prevalence } \\
(\%)\end{array}$ \\
\cline { 5 - 6 } C & Loanda & & 3,777 & 354 & 9.4 \\
D & Tapira & & 20,547 & 2,367 & 11.5 \\
E & Cascavel & & 3,397 & 320 & 9.4 \\
F & Vera Cruz do Oeste & & 1,869 & 232 & 12.4 \\
G & São João do Caiuá & & 12,914 & 1,069 & 8.3 \\
H & Paranavaín & & 27,335 & 2,926 & 10.7 \\
I & Roncador & & 7,062 & 1,421 & 20.1 \\
J & Nova Laranjeiras & & 1,868 & 283 & 15.1 \\
L & Centenário do Sul & & 4,484 & 441 & 9.8 \\
M & Santa Fé & & 8,489 & 1,259 & 14.8 \\
N & Grandes Rios & & 5,790 & 934 & 16.1 \\
O & Guairacá & & 752 & 68 & 9.0 \\
Q & Ortigueira & & 2,530 & 380 & 15.0 \\
R & Ponta Grossa & & 555 & 225 & 40.5 \\
V & Cruzmaltina & & 2,042 & 255 & 12.5 \\
TOTAL & & & 103,411 & 12,534 & $12.1^{b}$
\end{tabular}

acattle originated from neighbouring States and from regions $(A, B, K, S, T$, and $U$ ) that did not attain less than $0.5 \%$ of the total number of animals slaughtered.

bMean prevalence of BE in slaughtered cattle.

Table 3. Monthly prevalence of cattle slaughtered and infested with Eurytrema spp in Paraná, Brazil, 2000

\begin{tabular}{|c|c|c|c|c|c|c|}
\hline \multicolumn{3}{|c|}{ Animals slaughtered } & \multicolumn{4}{|c|}{ Animals infested by Eurytrema spp } \\
\hline Months & $\begin{array}{c}\text { Monthly } \\
\text { totals }\end{array}$ & $\begin{array}{l}\text { Relative } \\
\text { monthly }\end{array}$ & $\begin{array}{l}\text { Monthly } \\
\text { totals } \\
\text { totals ( } \% \text { ) }\end{array}$ & $\begin{array}{c}\text { Monthly } \\
\text { prevalence } \\
(\%)\end{array}$ & $\begin{array}{c}\text { Relative } \\
\text { prevalence } \\
(\%)\end{array}$ & $\begin{array}{l}\text { Comparative } \\
\text { Prevalence }^{1}\end{array}$ \\
\hline Jan & 7,749 & 7.5 & 1,050 & $13.6^{a}$ & $8.4^{a}$ & $0.9 *$ \\
\hline Feb & 7,890 & 7.6 & 1,069 & $13.5^{\mathrm{a}}$ & $8.5^{\mathrm{ab}}$ & $0.9 *$ \\
\hline Mar & 7,559 & 7.3 & 1,117 & $14.8^{\mathrm{b}}$ & $8.9^{b c}$ & $1.6^{*}$ \\
\hline Apr & 9,840 & 9.5 & 1,153 & $11.7^{\mathrm{C}}$ & $9.2^{\mathrm{bd}}$ & -0.3 \\
\hline May & 1,119 & 10.8 & 1,102 & $9.9^{b}$ & $8.8^{\text {acd }}$ & $-2.0 *$ \\
\hline Jun & 7,442 & 7.2 & 826 & $11.1^{\mathrm{b}}$ & 6.6 & $-0.6^{*}$ \\
\hline Jul & 8,322 & 8.0 & 992 & $11.9^{\mathrm{C}}$ & $7.9^{\text {be }}$ & -0.1 \\
\hline Aug & 5,441 & 5.3 & 540 & $9.9^{b}$ & 4.3 & $-1.0 *$ \\
\hline Sep & 7,744 & 7.5 & 957 & $12.4^{b}$ & $7.6^{\mathrm{e}}$ & 0.1 \\
\hline Oct & 9,008 & 8.7 & 1,112 & $12.3^{b}$ & $8.9^{\mathrm{acd}}$ & 0.2 \\
\hline Nov & 13,029 & 12.6 & 1,573 & $12.1^{\mathrm{b}}$ & 12.5 & 0.0 \\
\hline Dec & 8,268 & 8.0 & 1,043 & $12.6^{a, b}$ & $8.3^{\text {ace }}$ & 0.3 \\
\hline Total & 103,411 & 100 & 12.1 & 100 & & \\
\hline
\end{tabular}

${ }_{1}$ Difference obtained between the relative prevalence of animals infested and the relative prevalence of animals slaughtered (Westgard \& Hunt 1973). 2 Mean prevalence of BE in slaughtered cattle.

Subscript letters $(a, b, c, d, e)$ : numbers followed by different letters within the same column are significantly different $(P<0.05)$.

* Followed by numbers are significantly different $(\mathrm{P}<0.05)$.

November were significantly different $(P<0.05)$ from the other prevalences.

However, comparative prevalence (Table 3) was markedly reduced in May $(-2.00 \%$ with the highest comparative prevalence occurring in March (1.6\%). Significantly different $(\mathrm{P}<0.05)$ comparative prevalences were observed during 


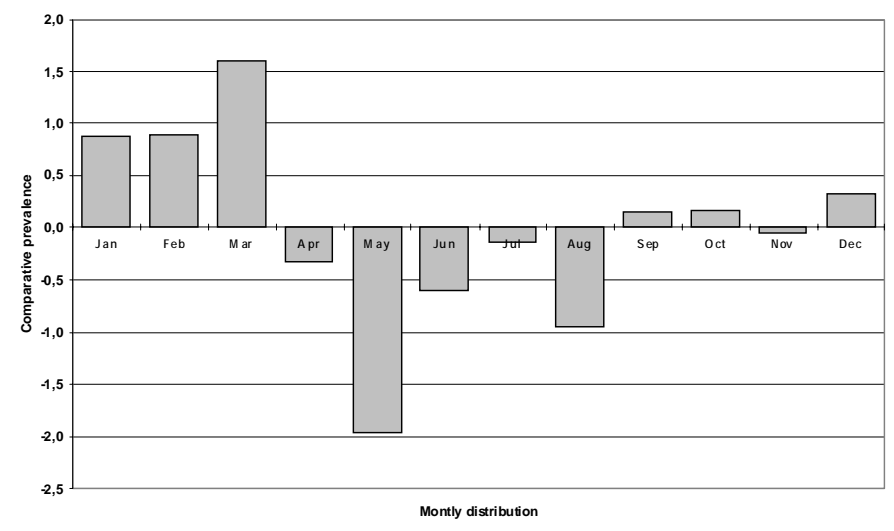

Fig.1. Comparative monthly prevalence of cattle infested with Eurytrema spp in the State of Paraná, Brazil, 2000.

the months of January, February, March, May, June and August, when compared with comparative prevalences observed during the other months. This prevalence was significantly reduced during the months of April to August, insignificant from September to December, and significantly higher from January to March (Fig. 1).

\section{DISCUSSION}

Data from this study indicate that BE is prevalent $(12.1 \%$ within the State of Paraná (Table 2). Similar results have been obtained in other Brazilian states. The disease has been considered endemic in the State of Minas Gerais, where $17.15 \%$ $(186 / 1,084)$ of the cattle examined from various towns were infected by Eurytrema spp (Brant \& Costa 1963). In another report, $80 \%$ of the properties evaluated in the State of São Paulo were shown to be positive for bovine eurytrematosis (Mattos Jr \& Vianna 1987). In Malaysia, 97\%(42/43) of the cattle examined demonstrated pancreases infected by Eurytrema spp (Basch 1966).

Cattle parasitized by Eurytrema spp (Table 1 and 2) originated from almost all geographical regions of the State of Paraná, so BE is a problem that must receive the attention of public health authorities. Even though this study demonstrates that $12.1 \%(12,534 / 103,411)$ of cattle slaughtered in the town of Maringá were positive for $\mathrm{BE}$ (Table 2), it must be stressed that this represents only $1.6 \%(12,534 / 800,831)$ of all cattle slaughtered, and $0.13 \%(12,534 / 9,900,885)$ of the cattle population in the State of Paraná, during the year 2000. This may suggest that BE in Paraná is not that serious as was previously reported in other States (Brant \& Costa 1963, Mattos Jr \& Vianna 1987), and consequently must be considered as hypoendemic and not simply endemic (Smith 1995). However more detailed parasitological, epidemiological, and pathological studies must be done to determine the real prevalence of BE within the State of Paraná.

The comparative prevalence (Table 3 ) of bovine eurytrematosis in Paraná was significantly different $(P<0.05)$ during the months of January, February, March, May, June and August, and significantly similar during the other months (Figure 1). This may suggest a possible seasonal variation of $B E$ in this State. The significant predominance of BE from January to March could be directly related to an increase in temperature which favors the transmission of the trematode, while during the colder season transmission was probably reduced. Other information such as the peculiarity of each region, the presence or absence of intermediate hosts and the amount of rainfall should also be considered. However more data must be collected to adequately evaluate the seasonal occurrence of this trematode in Paraná. Additionally detailed epidemiological studies must be done in Brazil to determine the actual intermediate hosts and possible means of transmission due to the potential zoonotic effect of this parasite (Mattos Jr \& Vianna 1987).

It can be concluded that bovine eurytrematosis occurs in almost all geographical regions within the State of Paraná and is hypoendemic. Prevalence is variable and may be directly bound to factors related to the biological cycle of the trematode, particularities of each region and environmental conditions.

Acknowledgements.- The authors thank Aristofanes Rosa and José Carlos Truiti of the Federal Inspection Service, Maringá, PR, for the access and utilization of the data presented in this study.

\section{REFERENCES}

Agresti A. 1990. Categorical Data Analysis. John Wiley \& Sons, New York..

Basch P.F. 1966. Patterns of transmission of the trematode Eurytrema pancreaticum in Malaysia. Am. J. Vet. Res. 27(116):239-240.

Brant P.C. \& Costa A.S. 1963. Distribuição geográfica da hidatidose, cisticerose, eurtrematose, dictiocaulose e fasciolose nos bovinos no Estado de Minas Gerais. Arq. Esc. Vet., Belo Horizonte, 15:47-59.

Headley S.A. 2000. Bovine eurytrematosis: life cycle, pathologic manifestations and public health considerations. Inic. Cient. Cesumar 2(2): 59-62.

Johnson R.A. 1992. Statistics Principles and Methods. 2nd ed. John Wiley \& Sons, New York.

Jubb K. V. F. 1993. The pancreas, p. 407 - 424. In: Jubb K.F.V., Kennedy P.C. \& Palmer P.C. (eds) Pathology of Domestic Animals. Vol.2. 4th ed. Academic Press, San Diego.

Mannigel R.C., Azevedo J.R., Headley S.A. \& Leonardo J.M.L. 2002. Bovine eurytrematosis: pathological considerations. In: Anais XII Congr. Bras. Parasitol. Vet., Rio de Janeiro.

Mattos Jr D.G \& Vianna S.S.S. 1987. O Eurytrema ceolmaticum (Trematoda: Dicrocoeliidae) no Brasil. Arq. Flum. Med. Vet. 2(1):3 -7.

SIDRA 2003. Sistema IBGE de Recuperação Automática. Available at: http:// www.sidra.ibge.gov.br Accessed on April 19, 2003.

Smith R.D. 1995. Veterinary Clinical Epidemiology: a problem oriented approach. 2nd ed. CRC Press, Boca Raton. 279p.

Soulsby E.J.L. 1982. Helminths, Arthropods and Protozoa of Domestic Animals. Lee and Faber, Philadelphia, p. 27-28.

Travassos L., Freitas J.F.T. \& Kohn A. 1969. Trematódeos do Brasil. Mem. Inst. Oswaldo Cruz 67:11-886.

Westgard J.O. \& Hunt M.R. 1973. Use and interpretation of common statistical tests in method-comparison studies. Clin. Chem. 19(49):49-57. 